THE MODULOR 



\title{
THE MODULOR
}

A Harmonious Measure

to the Human Scale

Universally applicable to

Architecture and Mechanics

\author{
by \\ LE CORBUSIER
}


Translation from French into English: Peter de Francia and Anna Bostock

A CIP catalogue record for this book is available

from the Library of Congress, Washington D.C., USA

Deutsche Bibliothek Cataloging-in-Publication Data

LeCorbusier:

The modulor / by LeCorbusier. [Transl. from French into Engl.:

Peter de Francia and Anna Bostock]. - Basel ; Boston ; Berlin : Birkhäuser

Einheitssacht.: Le modulor $<d t$.>

Franz. Ausg. u.d.T.: LeCorbusier: Le modulor

1. A harmonious measure to the human scale universally

applicable to architecture and mechanics. - Facs.-ed. of the 1. Engl. orig. ed., 1954. - 2000

ISBN 3-7643-6188-3 (Basel...)

ISBN 0-8176-6188-3 (Boston)

This work is subject to copyright. All rights are reserved, whether the whole or part of the material is concerned, specifically the rights of translation, reprinting, re-use of illustrations, recitation, broadcasting, reproduction on microfilms or in other ways, and storage in data bases. For any kind of use, permission of the copyright owner must be obtained.

Reprint, 2004

Reimpression of the first English edition published in 1954 by Faber and Faber.

(C) 2000 Birkhäuser - Publishers for Architecture, P.O.Box 133, CH-4010 Basel, Switzerland

(C) 2000 Fondation Le Corbusier, Paris

This book is also available in a French language edition (ISBN 3-7643-6187-5).

Printed on acid-free paper produced from chlorine-free pulp. TCF $\infty$

Printed in Germany

ISBN 3-7643-6188-3 (two volumes in slipcase)

ISBN 0-8176-6188-3 (two volumes in slipcase)

98765432 